\title{
Strategies to Combat Heat Stress in Broiler Chickens: Unveiling the Roles of Selenium, Vitamin E and Vitamin C
}

\author{
Majid Shakeri ${ }^{1}$, Ehsan Oskoueian ${ }^{2, *} \mathbb{B}$, Hieu Huu Le ${ }^{3}$ and Mehdi Shakeri ${ }^{4}$ \\ 1 Department of Medicine, The University of Washington, Seattle, WA 98195, USA; mshakeri@uw.edu \\ 2 Mashhad Branch, Agricultural Biotechnology Research Institute of Iran, Agricultural Research, Education, \\ and Extension Organization, Mashhad 511, Iran \\ 3 Faculty of Animal Sciences, Vietnam National University of Agriculture, Trau Quy, Gia Lam, \\ Hanoi 131004, Vietnam; lhhieu.hua@gmail.com \\ 4 Department of Animal Science and Agriculture, Ferdowsi University of Mashhad, Mashhad 511, Iran; \\ mehdi.shakeri95@gmail.com \\ * Correspondence: e.oskoueian@abrii.ac.ir
}

Received: 17 April 2020; Accepted: 28 May 2020; Published: 1 June 2020

\begin{abstract}
Heat stress compromises efficient poultry production by impairing growth performance and increasing mortality. Mechanisms to dissipate excess heat divert energy from efficient production. This includes increased energy expenditure for respiration, oxidative stress and micronutrient absorption. The fortification of diets with particular feed additives has been known as one of the most important approaches to minimize the negative impacts of heat stress on broiler production. In this context, the promising functional feed additives appeared to be selenium and vitamins $\mathrm{E}$ and $\mathrm{C}$. The fortification of broiler diets with these feed additives has been proven to enhance the function of vital organs, immune system response and growth performance of broilers under heat stress. The current review highlights recent successful experiences in the alleviation of heat stress symptoms in broilers using the above-mentioned additives. Selenium and vitamins $E$ and $C$ enhanced production performance in broiler chickens challenged with acute heat stress. The combination of these additives, by employing multiple mechanisms and through synergistic effects, improves heat stress symptoms more efficiently than their individual forms. Emerging literature reveals that selenium and vitamins $E$ and $C$ are involved in close interactions to protect proteins and lipids from oxidative damage and boost immune system function.
\end{abstract}

Keywords: functional feed additive; oxidative stress; vitamins; free radicals

\section{Introduction}

A high environmental temperature is one of the most important factors that causes heat stress among chickens and negatively affects poultry production [1]. Usually, the optimum temperature for growing broilers is 18 to $22^{\circ} \mathrm{C}$ [2], and any temperature higher than this range could cause heat stress [3]. Heat stress normally happens in the summer season when there is a negative balance between the environmental temperature and body heat production. In fact, chickens are confronted with three different ranges of temperature zones-the comfort zone, critical zone and upper critical zone. In the comfort zone $\left(18-25^{\circ} \mathrm{C}\right)$, chickens can maintain their body temperature with minimum effort, while in the critical zone $\left(26-35^{\circ} \mathrm{C}\right)$, maintaining body temperature requires the help of physical heat regulation. Furthermore, in the upper critical zone (higher than $35^{\circ} \mathrm{C}$ ), chickens cannot dissipate their body's heat and physiological disorders appear following multi-organ dysfunction, resulting in death [4] (Figure 1). 
Generally, under heat stress condition, chickens attempt to maintain their body temperature within the comfort zone to ensure the function of all vital organs. Thereby, they limit feed intake, walking and standing while increasing resting time, drinking and panting [5]. Under chronic heat stress, the continuous panting of the bird could alter the blood $\mathrm{pH}$ leading to respiratory alkalosis. Moreover, the changes in the blood $\mathrm{pH}$ impair the immune system's function and the body's hormonal activity [6].

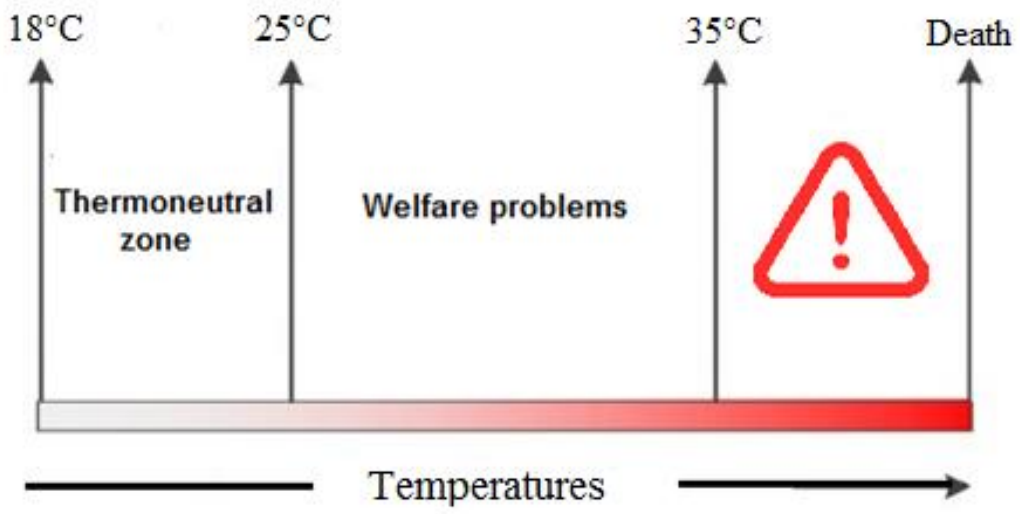

Figure 1. The temperature between the lower critical and upper critical temperatures (thermoneutral zone, $18-25^{\circ} \mathrm{C}$ ) is defined as the temperature zone in which chickens are able to keep their body temperature constant with the help of physical heat regulation (normal behaviors). In the critical zone, chickens are unable to keep their body temperature constant, resulting in welfare problems such as fast panting, physical tiredness $\left(26-35^{\circ} \mathrm{C}\right)$ and death $\left(<36^{\circ} \mathrm{C}\right)[7]$.

It is known that blood flow plays an important role in controlling the body's temperature. Under conditions of heat stress, the blood flow distribution is diverted from visceral to peripheral capillary beds for a rapid decrease in the body's temperature. On the other hand, the reduced visceral blood flow may cause hypoxia in the gastrointestinal tissues [8]. Hypoxia occurs when the body is deprived of an adequate oxygen supply such as during metabolism. The hypoxia in the gastrointestinal tract, particularly intestinal tissues, resulted in oxidative stress damage and increased permeability to pathogens and their related endotoxins $[9,10]$. Oxidative stress impairs the intestinal immune system's function, promotes mucosal and villus degeneration and causes enteric infections [11,12]. As a consequence, the digestion and absorption of the nutrients is interrupted, which could contribute to bone abnormalities, skeletal disorders and lameness [13].

It has been indicated that heat stress could alter the functions of the hypothalamic-pituitary axis and orthosympathic nervous system. As a result, the concentrations of thyroid hormones such as triiodothyronine $\left(\mathrm{T}_{3}\right)$ and thyroxine $\left(\mathrm{T}_{4}\right)$ were elevated, whereas the serum corticosterone concentration decreased. Emerging recent literature revealed that heat stress decreased feed intake and increased feed conversion ratios and mortality [14]. All these negative impacts resulted in low broiler production efficiency with high, significant economic losses [15]. Trace elements such as selenium are very important in the high-stress production condition. Recent findings indicated that both the level and the source of trace elements could play an important role in optimizing the production level, product quality and health status of the birds and economic returns [16].

A survey of recent progress in heat stress management in broilers revealed the potential applications of bioactive compounds (selenium and vitamins $\mathrm{C}$ and $\mathrm{E}$ ) as a feasible approach to combat heat stress symptoms. Therefore, due to the importance of these functional bioactive compounds in heat stress management, this review aimed to highlight the detailed information on how these bioactive compounds may contribute to alleviate heat stress symptoms in the broiler industry. 


\section{Bioactive Compounds in Heat Stress}

\subsection{Ascorbic Acid}

Ascorbic acid, ascorbate (the anion of ascorbic acid) or vitamin $C$ is a water-soluble antioxidant compound, which protects cells against oxidative damage and improves immune system function $[17,18]$. In fact, vitamin $C$ is not a part of any metabolic pathway, but it is an essential co-factor in many enzymatic reactions such as the synthesis of collagen, carnitine and catecholamine, and the metabolism of microsomes or the synthesis and catabolism of tyrosine.

Vitamin C activates the lysyl hydroxylase, prolyl-4-hydroxylase and prolyl-3-hydroxylase enzymes, which are involved in the conversion of peptide-bound proline and lysine into hydroxyproline and hydroxylysine. These conversions are essential for the formation of collagen. The collagen is essential for the development and maintenance of blood vessels, scar tissue, cartilage and bones. The fibril networks of collagen are also critical in bone formation through mineralization with hydroxyapatite under the influence of active metabolites of vitamin $\mathrm{D}_{3}$. It has also been reported to improve bone-breaking strength through increased collagen synthesis, the enhanced binding capacity of calcium-binding proteins and the mineralization process [18-20].

In the carnitine pathway, the protein is degraded to 3-hydroxy-6-N-trimethyllysine by 6-N-trimethyllysine hydroxylase, and the resulting product, into gamma-butyrobetaine hydroxylase and glycine. Then, gamma-butyrobetaine hydroxylase is hydroxylated to carnitine. In this process, the conversion of trimethyllysine to 3-hydroxy-trimethyllysine and 4-butyrobetaine to carnitine occurs in the presence of vitamin C. Carnitine plays a major role in essential metabolic pathways, imports activated fatty acids into the mitochondrion for ATP generation and functions as an osmolyte in the cytoplasm [21].

Vitamin C is a co-factor of dopamine beta hydroxylase, which participates in the conversion of dopamine to norepinephrine in neural tissues [22]. Norepinephrine levels generally increase during stress and increase heart rate and blood pressure, increase blood glucose, increase blood flow to skeletal muscle and reduce blood flow to and the motility of the gastrointestinal tract.

In addition to the biosynthesis of norepinephrine, vitamin $C$ appeared to be essential in the bioconversion of tyrosine to other catecholamines such as dopamine, noradrenaline and adrenaline [23-25]. In fact, tyrosine is a precursor to neurotransmitters and increases plasma neurotransmitter levels under stressful conditions. Various studies have indicated that supplementation with tyrosine and vitamin $C$ during stress could reduce stress hormones and weight loss in animal trials $[26,27]$. The available information has also confirmed that vitamin $C$ is not only involved in hormone biosynthesis but also increases their stability and activity through an amidation process with the help of an enzyme called peptidylglycine alpha-amidating monooxygenase. Vitamin $\mathrm{C}$ has also been shown to regulate the body's temperature, synthesis of 1,25-dihydroxy vitamin D, and function of the immune system. Vitamin $C$ is present in high concentrations in the immune cells, and it is depleted quickly during stress conditions. It is not exactly clear how vitamin $\mathrm{C}$ boosts immune system function, but some of available evidence indicates the effects of vitamin $C$ on phagocytes, the production of cytokines, lymphocytes and the number of cell adhesion molecules in monocytes [28,29].

Vitamin C may act as co-antioxidant with other antioxidants by synergistic effects. In the research conducted by Doba et al. [30], the antioxidant activity of vitamin E increased in the presence of vitamin $C$ through reducing tocopheroxy radicals back to their active form of vitamin E. Emerging literature revealed that adult poultry are capable of synthesizing vitamin $C$ to meet their requirements in normal conditions. However, it has been found that their requirements increase during stress, and several studies have reported the beneficial effects of the dietary supplementation of poultry feed with ascorbic acid [17,31]. Dietary supplementation with vitamin C limited and alleviated stress metabolic signs, improved performance, enhanced immunological status and reduced mortality. The literature survey indicated that the optimum response in terms of the growth performance, feed conversion ratio, feed efficiency, survival rate and carcass quality in broilers under heat stress appeared 
to occur with average supplements of $250 \mathrm{mg} / \mathrm{kg}$ vitamin C. However, the required vitamin C in laying hens to observe optimum feed efficiency, egg production and egg quality under heat stress is about $200-500 \mathrm{mg} / \mathrm{kg}[17,32-36]$.

There is a close relationship between vitamin $C$ with vitamin $E$, whereas both have positive impacts on the immune system by enhancing antibody production, macrophage activity and humoral immunity in broiler chicks. Therefore, a combination of these two vitamins could improve the immune response and performance of broiler chickens.

\subsection{Vitamin $E$}

Vitamin E is a group of compounds containing both tocopherols and tocotrienols, which are fat-soluble with antioxidant properties [37]. Vitamin E protects the cell membranes and tissues from lipoperoxidative damage induced by free radicals $[38,39]$ and acts as a cellular enzymatic activity regulator [40]. Alpha-tocopherol is the most biologically active form of vitamin $\mathrm{E}$, which is involved in the glutathione peroxidase pathway and protects organisms from oxidative damage by reacting with lipid radicals produced in the lipid peroxidation reaction. The oxidized alpha-tocopherol radicals recycle back to the active reduced form through reduction by other antioxidants such as ascorbate. Ascorbic acid acts as an antioxidant or a prooxidant and helps to maintain vitamin E levels through reducing the degradative metabolism of vitamin $\mathrm{E}$ and then increases the antioxidant effectiveness.

The fat-soluble nature of vitamin $\mathrm{E}$ renders it as a suitable cell membrane antioxidant against oxidative damage. Moreover, vitamin E modulates the activity of protein kinase $\mathrm{C}$ (PC) and controls smooth muscle growth and proliferation. Vitamin E activates a dephosphorylation enzyme called protein phosphatase 2, which cuts phosphate groups from PC and results in the inactivation of PC and smooth muscle growth inhibition [41,42]. Poultry vitamin E requirements should be provided for through dietary supplementation as they are not capable of vitamin E synthesis. Under stress conditions, particularly heat stress, the levels of hormones like corticosterone and catecholamines increase and lipid peroxidation in cells membranes is initiated.

Vitamin E has also been reported to protect lymphocytes, macrophages and plasma cells against oxidative damage and improves their survival, proliferation and function. Thus, dietary supplementation with vitamin $\mathrm{E}$ under stress conditions enhances the immune response [43]. Emerging literature reveals that the addition of vitamin $\mathrm{E}$ at an average concentration of $250 \mathrm{mg} / \mathrm{kg}$ is a feasible protective practice to alleviate the symptoms of heat stress and may result in optimum performance and improved meat quality in broiler chickens [44,45]. However, this concentration for layers is $125-250 \mathrm{mg} / \mathrm{kg}$, which leads to an enhanced immune response, egg production and feed conversion ratio $[43,44,46]$. The improved egg production under heat stress conditions appeared to be through protecting the liver from lipid peroxidation and cell membrane damage, which resulted in plasma egg yolk precursors increasing, including very low density lipoprotein and vitellogenin [47]. It could facilitate the regeneration of oxidative stress-damaged tissues [48] and enhances neurological function [49]. Heat stress increases the concentration of malonyldialdehyde in the serum and liver, whereas vitamin E reduces the synthesis of malonyldialdehyde in the liver by acting against lipid peroxidation and cell damage [50] and results in the improvement of the chicken's performance [51,52].

Phenolics, flavonoids, saponins and alkaloids are major plant bioactive compounds with potential antioxidant activity. Earlier research indicated that plant bioactive compounds with antioxidant activity work synergistically with vitamin $\mathrm{E}$ and intensify the antioxidant potential of vitamin $\mathrm{E}$ [53]. Besides phytogenics, zinc is an element that is important in carbohydrate metabolism, protein synthesis $[54,55]$ and adjusting insulin levels, which are important in glucose pathway [56,57]; the production of epithelial cells, which are one of the intestinal barriers against harmful external organisms [55]; and T-cell and immune system functions [58,59]. Under heat stress conditions, zinc (30-60 mg/kg) has synergistic effects with vitamin E, and their combination positively affects laying hens' health and egg production [60-62] and the performance of broilers [63,64]. The combination of vitamin E and zinc is considered as an important antioxidant shield for broilers against heat stress $[65,66]$. 
Furthermore, there is also a close relationship between selenium and vitamin E; both act to improve the immune system. It needs to be mentioned that different sources of selenium provide different alterations in the immune system.

\subsection{Selenium}

Selenium is an essential micronutrient and can be found in two forms as inorganic (selenate and selenite) and organic forms (selenomethionine and selenocysteine). Selenium functions as a co-factor for antioxidant enzymes including glutathione peroxidase, superoxide dismutase and thioredoxin reductase. Glutathione peroxidase removes reactive oxygen species, protects cells against oxidative stress damage [67], and prevents lipid and protein oxidation [68]. Furthermore, selenium is considered as a co-factor for iodothyronine deiodinase enzymes, which are involved in the activation or inactivation of the initially released hormone $T_{4}$ to $T_{3}$ or reverse triiodothyronine $\left(\mathrm{rT}_{3}\right)$. Thus, selenium, by the indirect regulation of $\mathrm{T}_{3}$ and $\mathrm{T}_{4}$ production, affects the basal metabolic rate, protein synthesis, and the metabolism of fat, carbohydrate, protein and vitamins. It is known that under physiological, pathological or environmental stimuli, the synthesis of thyroid hormones is impaired and supplementing with selenium effectively regulates the synthesis of thyroid hormones and restores body homeostasis.

Initially, the organic or inorganic forms of selenium compound are transformed to hydrogen selenide. Selenomethionine could act as methionine functions or be transformed to selenocysteine via the trans-sulfuration pathway. Then, selenocysteine may be transformed to hydrogen selenide. Selenate is reduced to selenite by glutathione and then hydrogen selenite. Selenophosphate synthetase converts the hydrogen selenite to selenophosphate. Then, it reacts with L-seryl-tRNASec to form L-selenocysteinyl-tRNASec, which then further forms the selenoproteins. A selenoprotein is any protein containing selenocysteine, and common selenoproteins are glutathione peroxidase and thioredoxin reductase, which are involved in oxidative damage and thyroid hormone metabolism, respectively. The function of the immune system has also been enhanced in the presence of these two selenoproteins $[69,70]$.

Early studies in broilers indicated that dietary supplementation with selenium at doses ranging from 0.4 to $1 \mathrm{mg} / \mathrm{kg}$ significantly enhanced growth performance when chickens were exposed to heat stress [71,72]. These results were further attributed to the effects of selenium on thyroid hormone metabolism, DNA synthesis, cellular antioxidant levels and immune system responses [73-75].

\section{Conclusions}

Considering new techniques to cope with heat stress, which has an adverse influence on the performance and meat quality during the rearing period, is a main aim of the poultry industry. In order to enhance chickens' tolerance to high temperature, understanding the functions of different supplementations and manipulating diets seem to be promising methods to reduce the adverse effects of heat stress quickly. The synergistic effects of selenium and vitamins $\mathrm{E}$ and $\mathrm{C}$ enhance growth performance in broiler chickens challenged with acute heat stress, employing multiple mechanisms. Emerging literature reveals that selenium and vitamins $E$ and $C$ have close interactions to protect proteins and lipids from oxidative damage, and a combination of them can be considered as an important solution to cope with heat stress. Both vitamins $C$ and $E$ play an important role in tissues: scavenging oxygen radicals, resulting in the improvement of the immune system. Furthermore, vitamin $\mathrm{C}$ regenerates vitamin $\mathrm{E}$ by reducing the vitamin $\mathrm{E}$ radicals formed. Meanwhile, selenium is involved in the glutathione pathway, which is part of the ascorbate cycle.

Author Contributions: M.S. (Majid Shakeri) and E.O. prepared and revised the manuscript. H.H.L. and M.S. (Mehdi Shakeri) revised the manuscript. The authors contributed equally to approve the final manuscript. All authors have read and agreed to the published version of the manuscript.

Funding: This research received no external funding. 
Conflicts of Interest: The authors declare no conflict of interest.

\section{References}

1. Meremikwu, V.; Ibekwe, H.; Essien, A. Improving broiler performance in the tropics using quantitative nutrition. World's Poult. Sci. J. 2013, 69, 633-638. [CrossRef]

2. Sahin, N.; Sahin, K.; Onderci, M.; Karatepe, M.; Smith, M.; Kucuk, O. Effects of dietary lycopene and vitamin E on egg production, antioxidant status and cholesterol levels in Japanese quail. Asian Australas. J. Anim. Sci. 2006, 19, 224. [CrossRef]

3. Daghir, N. Nutritional strategies to reduce heat stress in broilers and broiler breeders. Lohmann Inf. 2009, 44, 6-15.

4. Sohail, M.; Hume, M.; Byrd, J.; Nisbet, D.; Ijaz, A.; Sohail, A.; Shabbir, M.; Rehman, H. Effect of supplementation of prebiotic mannan-oligosaccharides and probiotic mixture on growth performance of broilers subjected to chronic heat stress. Poult. Sci. 2012, 91, 2235-2240. [CrossRef]

5. Suganya, T.; Senthilkumar, S.; Deepa, K.; Amutha, R. Nutritional management to alleviate heat stress in broilers. Int. J. Sci. EnDVOi Technol. 2015, 4, 661-666.

6. Mack, L.; Felver-Gant, J.; Dennis, R.; Cheng, H.W. Genetic variations alter production and behavioral responses following heat stress in 2 strains of laying hens. Poult. Sci. 2013, 92, 285-294. [CrossRef]

7. Youssef, A.; Exadaktylos, V.; Berckmans, D.A. Towards real-time control of chicken activity in a ventilated chamber. Biosyst. Eng. 2015, 135, 31-43. [CrossRef]

8. Hall, D.M.; Buettner, G.R.; Oberley, L.W.; Xu, L.; Matthes, R.D.; Gisolfi, C.V. Mechanisms of circulatory and intestinal barrier dysfunction during whole body hyperthermia. Am. J. Physiol.-Heart Circ. Physiol. 2001, 280, H509-H521. [CrossRef]

9. Pearce, S.C.; Mani, V.; Boddicker, R.L.; Johnson, J.S.; Weber, T.E.; Ross, J.W.; Rhoads, R.P.; Baumgard, L.H.; Gabler, N.K. Heat stress reduces intestinal barrier integrity and favors intestinal glucose transport in growing pigs. PLoS ONE 2013, 8, e70215. [CrossRef]

10. Shakeri, M.; Cottrell, J.J.; Wilkinson, S.; Zhao, W.; Le, H.H.; McQuade, R.; Furness, J.B.; Dunshea, F.R. Dietary Betaine Improves Intestinal Barrier Function and Ameliorates the Impact of Heat Stress in Multiple Vital Organs as Measured by Evans Blue Dye in Broiler Chickens. Animals 2020, 10, 38. [CrossRef]

11. Oskoueian, E.; Abdullah, N.; Idrus, Z.; Ebrahimi, M.; Goh, Y.M.; Shakeri, M.; Oskoueian, A. Palm kernel cake extract exerts hepatoprotective activity in heat-induced oxidative stress in chicken hepatocytes. BMC Complementary Altern. Med. 2014, 14, 1. [CrossRef]

12. Quinteiro-Filho, W.; Ribeiro, A.; Ferraz-de-Paula, V.; Pinheiro, M.; Sakai, M.; Sá, L.; Ferreira, A.; Palermo-Neto, J. Heat stress impairs performance parameters, induces intestinal injury, and decreases macrophage activity in broiler chickens. Poult. Sci. 2010, 89, 1905-1914. [CrossRef]

13. Gabler, N.; Pearce, S. The impact of heat stress on intestinal function and productivity in grow-finish pigs. Anim. Prod. Sci. 2015, 55, 1403-1410. [CrossRef]

14. Piekarski, A.; Bottje, W.; Dridi, S. Heat stress: A global concern. Adv. Food Technol. Nutr. Sci. 2015, 1, $102-103$. [CrossRef]

15. Lan, X.; Schmidt, C.J.; Lamont, S.J. Heat-Susceptible and Heat-Resistant Chicken Lines Reveal Differentially Expressed Genes in Liver in Response to Heat Stress. Anim. Ind. Rep. 2016, 662, 56.

16. Attia, Y.; Abdalah, A.; Zeweil, H.; Bovera, F.; El-Din, A.T.; Araft, M.J.C.J.A.S. Effect of inorganic or organic selenium supplementation on productive performance, egg quality and some physiological traits of dual-purpose breeding hens. Czech. J. Anim. Sci. 2010, 55, 505-519. [CrossRef]

17. Abidin, Z.; Khatoon, A. Heat stress in poultry and the beneficial effects of ascorbic acid (vitamin C) supplementation during periods of heat stress. World's Poult. Sci. J. 2013, 69, 135-152. [CrossRef]

18. Lohakare, J.; Ryu, M.; Hahn, T.-W.; Lee, J.; Chae, B. Effects of supplemental ascorbic acid on the performance and immunity of commercial broilers. J. Appl. Poult. Res. 2005, 14, 10-19. [CrossRef]

19. Lohakare, J.; Chae, B.; Hahn, T. Effects of feeding methods (water vs. feed) of vitamin $\mathrm{C}$ on growth performance and carcass characteristics in broiler chickens. Asian Australas. J. Anim. Sci. 2004, 17, 1112-1117. [CrossRef]

20. Dar, T.A.; Singh, L.R. Protein Modificomics: From Modifications to Clinical Perspectives; Academic Press: Cambridge, MA, USA, 2019. 
21. Cánovas, M.; Bernal, V.; Sevilla, A.; Iborra, J. Salt stress effects on the central and carnitine metabolisms of Escherichia coli. Biotechnol. Bioeng. 2007, 96, 722-737. [CrossRef]

22. Harrison, F.E.; May, J.M. Vitamin C function in the brain: Vital role of the ascorbate transporter SVCT2. Free Radic. Biol. Med. 2009, 46, 719-730. [CrossRef]

23. Combs, G.F., Jr.; McClung, J.P. The Vitamins: Fundamental Aspects in Nutrition and Health; Academic Press: Cambridge, MA, USA, 2016.

24. Rush, R.; Geffen, L. Dopamine $\beta$-hydroxylase in health and disease. CRC Crit. Rev. Clin. Lab. Sci. 1980, 12, 241-277. [CrossRef]

25. Furusawa, H.; Sato, Y.; Tanaka, Y.; Inai, Y.; Amano, A.; Iwama, M.; Kondo, Y.; Handa, S.; Murata, A.; Nishikimi, M. Vitamin C is not essential for carnitine biosynthesis in vivo: Verification in vitamin C-depleted senescence marker protein-30/gluconolactonase knockout mice. Biol. Pharm. Bull. 2008, 31, 1673-1679. [CrossRef]

26. Hao, S.; Avraham, Y.; Bonne, O.; Berry, E.M. Separation-induced body weight loss, impairment in alternation behavior, and autonomic tone: Effects of tyrosine. Pharmacol. Biochem. Behav. 2001, 68, 273-281. [CrossRef]

27. Peeters, E.; Neyt, A.; Beckers, F.; De Smet, S.; Aubert, A.; Geers, R. Influence of supplemental magnesium, tryptophan, vitamin C, and vitamin E on stress responses of pigs to vibration. J. Anim. Sci. 2005, 83, 1568-1580. [CrossRef]

28. Watson, R.R.; Zibadi, S.; Preedy, V.R. Dietary Components and Immune Function; Springer Science \& Business Media: New York, NY, USA, 2010.

29. Sorice, A.; Guerriero, E.; Capone, F.; Colonna, G.; Castello, G.; Costantini, S. Ascorbic acid: Its role in immune system and chronic inflammation diseases. Mini Rev. Med. Chem. 2014, 14, 444-452. [CrossRef]

30. Doba, T.; Burton, G.W.; Ingold, K.U. Antioxidant and co-antioxidant activity of vitamin C. The effect of vitamin C, either alone or in the presence of vitamin E or a water-soluble vitamin E analogue, upon the peroxidation of aqueous multilamellar phospholipid liposomes. Biochim. Biophys. Acta 1985, 835, 298-303. [CrossRef]

31. Maurice, D.; Lightsey, S.; Toler, J. Ascorbic acid biosynthesis in hens producing strong and weak eggshells. Br. Poult. Sci. 2004, 45, 404-408. [CrossRef]

32. Sahin, K.; Kucuk, O.; Sahin, N.; Sari, M. Effects of Vitamin C and Vitamin E on Lipid Peroxidation Status, Serum Hormone, Metabolite, and Mineral Concentrations of Japanese Quails Reared under Heat Stress $\left(34{ }^{\circ} \mathrm{C}\right)$. Int. J. Vitam. Nutr. Res. 2002, 72, 91-100. [CrossRef]

33. Mahmoud, K.Z.; Edens, F.; Eisen, E.; Havenstein, G. Ascorbic acid decreases heat shock protein 70 and plasma corticosterone response in broilers (Gallus gallus domesticus) subjected to cyclic heat stress. Comp. Biochem. Physiol. Part B Biochem. Mol. Biol. 2004, 137, 35-42. [CrossRef]

34. Ali, M.; Howlider, M.; Azad, A.; Rahman, M. Vitamin C and electrolyte supplementation to support growth and meat yield of broilers in a hot humid environment. J. Bangladesh Agric. Univ. 2010, 8, 57-60. [CrossRef]

35. Asli, M.M.; Hosseini, S.A.; Lotfollahian, H.; Shariatmadari, F. Effect of probiotics, yeast, vitamin E and vitamin $C$ supplements on performance and immune response of laying hen during high environmental temperature. Int. J. Poult. Sci. 2007, 6, 895-900. [CrossRef]

36. Seven, I.; Aksu, T.; Seven, P.T. The effects of propolis on biochemical parameters and activity of antioxidant enzymes in broilers exposed to lead-induced oxidative stress. Asian-Australas. J. Anim. Sci. 2010, 23, 1482-1489. [CrossRef]

37. Packer, L.; Weber, S.U.; Rimbach, G. Molecular aspects of $\alpha$-tocotrienol antioxidant action and cell signalling. J. Nutr. 2001, 131, 369S-373S. [CrossRef]

38. Gao, J.; Lin, H.; Wang, X.; Song, Z.; Jiao, H. Vitamin E supplementation alleviates the oxidative stress induced by dexamethasone treatment and improves meat quality in broiler chickens. Poult. Sci. 2010, 89, 318-327. [CrossRef]

39. Traber, M.G.; Stevens, J.F. Vitamins C and E: Beneficial effects from a mechanistic perspective. Free Radic. Biol. Med. 2011, 51, 1000-1013. [CrossRef]

40. Schneider, C. Chemistry and biology of vitamin E. Mol. Nutr. Food Res. 2005, 49, 7-30. [CrossRef]

41. Azzi, A.; Boscoboinik, D.; Clement, S.; Ozer, N.K.; Ricciarelli, R.; Stocker, A.; Tasinato, A.; Sirikci, O. Signalling functions of alpha-tocopherol in smooth muscle cells. Int. J. Vitam. Nutr. Res. Int. Z. Vitam. Ernahr. J. Int. Vitaminol. Nutr. 1997, 67, 343-349. 
42. Liu, Y.; Hyde, A.S.; Simpson, M.A.; Barycki, J.J. Emerging regulatory paradigms in glutathione metabolism. In Advances in Cancer Research; Elsevier: Amsterdam, The Netherlands, 2014; Volume 122, pp. 69-101.

43. Attia, Y.A.; Abd El-Hamid, A.E.-H.E.; Abedalla, A.A.; Berika, M.A.; Al-Harthi, M.A.; Kucuk, O.; Sahin, K.; Abou-Shehema, B.M. Laying performance, digestibility and plasma hormones in laying hens exposed to chronic heat stress as affected by betaine, vitamin C, and/or vitamin E supplementation. SpringerPlus 2016, 5, 1619. [CrossRef]

44. Jiang, W.; Zhang, L.; Shan, A. The effect of vitamin E on laying performance and egg quality in laying hens fed corn dried distillers grains with solubles. Poult. Sci. 2013, 92, 2956-2964. [CrossRef]

45. Habibian, M.; Ghazi, S.; Moeini, M.M.; Abdolmohammadi, A. Effects of dietary selenium and vitamin E on immune response and biological blood parameters of broilers reared under thermoneutral or heat stress conditions. Int. J. Biometeorol. 2014, 58, 741-752. [CrossRef]

46. Kirunda, D.; Scheideler, S. The efficacy of vitamin E (DL- $\alpha$-tocopheryl acetate) supplementation in hen diets to alleviate egg quality deterioration associated with high temperature exposure. Poult. Sci. 2001, 80, 1378-1383. [CrossRef]

47. Bollengier-Lee, S. Optimal dietary concentration of vitamin E for alleviating the effect of heat stress on egg production in laying hens. Br. Poult. Sci. 1999, 40, 102-107. [CrossRef]

48. Villacorta, L.; Graça-Souza, A.V.; Ricciarelli, R.; Zingg, J.-M.; Azzi, A. $\alpha$-Tocopherol induces expression of connective tissue growth factor and antagonizes tumor necrosis factor- $\alpha$-mediated downregulation in human smooth muscle cells. Circ. Res. 2003, 92, 104-110. [CrossRef]

49. Muller, D.P. Vitamin E and neurological function. Mol. Nutr. Food Res. 2010, 54, 710-718. [CrossRef]

50. McDowell, L.R. Vitamins in Animal Nutrition: Comparative Aspects to Human Nutrition; Elsevier: Amsterdam, The Netherlands, 2012.

51. Sahin, K.; Kucuk, O. Effects of vitamin C and vitamin E on performance, digestion of nutrients and carcass characteristics of Japanese quails reared under chronic heat stress (34 C). J. Anim. Physiol. Anim. Nutr. 2001, 85, 335-341. [CrossRef]

52. Sahin, K.; Sahin, N.; Onderci, M.; Yaralioglu, S.; Kucuk, O. Protective role of supplemental vitamin E on lipid peroxidation, vitamins E, A and some mineral concentrations of broilers reared under heat stress. Vet. Med. (Praha)- 2001, 46, 140-144. [CrossRef]

53. Sonam, K.; Guleria, S. Synergistic antioxidant activity of natural products. Annal. Pharmacol. Pharm. 2017, 2, 1086.

54. Pond, W.G.; Church, D.C.; Pond, K.R. Basic Animal Nutrition and Feeding; John Wiley and Sons: Hoboken, NJ, USA, 1995.

55. Costa, M. O papel do zinco e do cromo no desempenho de porcas. PorkworldPaulínia 2005, 4, 58-60.

56. Linder, M. Nutritional and metabolism of the trace elements. In Nutritional Biochemistry and Metabolism with Clinical Applications; Elsevier: New York, NY, USA, 1991; pp. 215-276.

57. MacDonald, R.S. The role of zinc in growth and cell proliferation. J. Nutr. 2000, 130, 1500S-1508S. [CrossRef]

58. Powell, J.; Borchers, A.T.; Yoshida, S.; Gershwin, M.E. Evaluation of the immune system in the nutritionally at-risk host. In Nutrition and Immunology; Springer: Berlin/Heidelberg, Germany, 2000; pp. 21-31.

59. Ibs, K.-H.; Rink, L. Zinc-altered immune function. J. Nutr. 2003, 133, 1452S-1456S. [CrossRef]

60. Sahin, K.; Kucuk, O. Zinc supplementation alleviates heat stress in laying Japanese quail. J. Nutr. 2003, 133, 2808-2811. [CrossRef]

61. Onderci, M.; Sahin, N.; Sahin, K.; Kilic, N. Antioxidant properties of chromium and zinc. Biol. Trace Elem. Res. 2003, 92, 139-149. [CrossRef]

62. Kucuk, O.; Kahraman, A.; Kurt, I.; Yildiz, N.; Onmaz, A. A combination of zinc and pyridoxine supplementation to the diet of laying hens improves performance and egg quality. Biol. Trace Elem. Res. 2008, 126, 165-175. [CrossRef]

63. Salgueiro, M.J.; Zubillaga, M.; Lysionek, A.; Sarabia, M.I.; Caro, R.; De Paoli, T.; Hager, A.; Weill, R.; Boccio, J. Zinc as an essential micronutrient: A review. Nutr. Res. 2000, 20, 737-755. [CrossRef]

64. Kim, E.-S.; Noh, S.K.; Koo, S.I. Marginal zinc deficiency lowers the lymphatic absorption of $\alpha$-tocopherol in rats. J. Nutr. 1998, 128, 265-270. [CrossRef]

65. Prasad, A.S.; Kucuk, O. Zinc in cancer prevention. Cancer Metastasis Rev. 2002, 21, 291-295. [CrossRef]

66. Tate, D.J.; Miceli, M.V.; Newsome, D.A. Zinc protects against oxidative damage in cultured human retinal pigment epithelial cells. Free Radic. Biol. Med. 1999, 26, 704-713. [CrossRef] 
67. Tappel, A.; Tappel, A. Oxidant free radical initiated chain polymerization of protein and other biomolecules and its relationship to diseases. Med Hypotheses 2004, 63, 98-99. [CrossRef]

68. Nunes, V.A.; Gozzo, A.J.; Cruz-Silva, I.; Juliano, M.A.; Viel, T.A.; Godinho, R.O.; Meirelles, F.V.; Sampaio, M.U.; Sampaio, C.A.; Araujo, M.S. Vitamin E prevents cell death induced by mild oxidative stress in chicken skeletal muscle cells. Comp. Biochem. Physiol. Part C Toxicol. Pharmacol. 2005, 141, 225-240. [CrossRef] [PubMed]

69. Hoffmann, P.R. Mechanisms by which selenium influences immune responses. Arch. Immunol. Ther. Exp. 2007, 55, 289-297. [CrossRef] [PubMed]

70. Best, B. Selenium: AntiOxidant, Anti-Carcinogen, and Immune System Booster. Tanggal 2007. Available online: http://www.benbest.com/nutrceut/Selenium.html (accessed on 27 October 2017).

71. Ibrahim, M.; Eljack, B.; Fadlalla, I. Selenium supplementation to broiler diets. Anim. Sci. J. 2011, 2, 12-17.

72. Krstić, B.; Jokić, Ž.; Pavlović, Z.; Živković, D. Options for the production of selenized chicken meat. Biol. Trace Elem. Res. 2012, 146, 68-72. [CrossRef]

73. Niu, Z.; Liu, F.; Yan, Q.; Li, L. Effects of different levels of selenium on growth performance and immunocompetence of broilers under heat stress. Arch. Anim. Nutr. 2009, 63, 56-65. [CrossRef]

74. Habibian, M.; Ghazi, S.; Moeini, M.M. Effects of dietary selenium and vitamin E on growth performance, meat yield, and selenium content and lipid oxidation of breast meat of broilers reared under heat stress. Biol. Trace Elem. Res. 2016, 169, 142-152. [CrossRef]

75. Tayeb, I.; Qader, G.K. Effect of feed supplementation of selenium and vitamin E on production performance and some hematological parameters of broiler. Kahramanmaras Sutcu Imam Univ. J. Nat. Sci. 2012, 15, 46-56.

(C) 2020 by the authors. Licensee MDPI, Basel, Switzerland. This article is an open access article distributed under the terms and conditions of the Creative Commons Attribution (CC BY) license (http://creativecommons.org/licenses/by/4.0/). 